\title{
Embodying Alternatives to Capitalism in the 21st Century
}

\author{
Lara Monticelli
}

Independent researcher, monticelli.lara@gmail.com

\begin{abstract}
The goal of this article is twofold. First, to illustrate how in the last decade a growing number of critical and Marxist thinkers committed to discussing and developing theories of change have started to broaden their focus by including social movements and grassroots initiatives that are "interstitial", i.e. initiatives that are developing within capitalism and are striving to prefigure a post-capitalist society in the here and now without engaging in contentious, violent and revolutionary actions and activities. To achieve this, I mainly focus on the work of four authors: Erik Olin Wright, John Holloway, Ana C. Dinerstein, and Luke Martell. The second goal of this article is to understand why these interstitial movements are getting so much attention from critical scholars and to argue that the time is ripe for establishing a theory of (and for) prefigurative social movements. The article closes with some brief reflections on the future of radical thinking that includes an invitation, directed mostly at the young generation of critical and Marxist scholars, to begin a dialogue with theories of change developed within other disciplines, to engage with activists, and to experiment with participatory methods and techniques.
\end{abstract}

Keywords: Karl Marx, bicentenary, 200th anniversary, capitalism, crisis, utopia, prefigurative social movements

Acknowledgement: The following text constitutes an expanded and revised version of the semi-plenary talk that I gave at the 13th conference of the European Sociological Association (ESA) held in Athens in August 2017. The general theme of the conference that year was "UnMaking Europe: Capitalism, Solidarities, Subjectivities" and the title of my talk was "Embodying the Critique to Capitalism in Gloomy Times: Theoretical Perspectives and Potential Research Horizons on Emerging Real Utopias". I'd like to take this opportunity to express my gratitude to Christian Fuchs, Torsten Geelan, and Francesca Forno for their invaluable feedback on the preliminary draft of this article. The ideas shared in this article are the fruit of more than two years of discussions, debates, and reflections that l've had the pleasure to participate in as the co-organiser and co-chair of two mini-conferences focusing on "Re-Embedding the Social: Cooperatives, Political Consumerism and Alternative Lifestyles". These were organised as part of the annual meetings of the Society for the Advancement of Socio-Economics (SASE) and held at the University of California, Berkeley (2016), and at the University Claude Bernard in Lyon (2017). I am grateful to all the participants and especially to my co-organizers, Francesca Forno, Torsten Geelan and Paolo R. Graziano, for the stimulating and constructive sessions we've built together.

"The philosophers have only interpreted the world, in various ways. The point, however, is to change it." (Karl Marx, 11th Thesis on Feuerbach)

\section{Introduction: The Beginning of the End?}

The deleterious effects of contemporary capitalism were evident long before the socalled Great Recession. I am referring here to the reproduction of exploitative mechanisms towards workers, the financialisation of the economy, the skyrocketing inequalities of income both between and within countries, the complicity between politicians and multinational corporations, the accumulation by dispossession, the diffusion of 
mass-consumerism and commodity fetishism, the degradation of the environment and depletion of natural resources; the pollution of our air, land and sea; and alarming levels of global warming. Already in the late 20th century there was evidence of an unprecedented wave of mobilisations and protest on a global scale against what was identified as the system driving all these destructive phenomena: profit-driven globalisation. Claims for a more just, egalitarian and sustainable economic system were embraced by the alter-globalisation movement under the popular slogan "Another World is Possible". But it was not until the financial collapse of 2008-2009 that the debate passed from an accusation of the adverse effects of globalisation to a systemic critique of expansionary global capitalism and its economic, social and environmental consequences.

The financial crisis and the subsequent austerity measures imposed by both rightwing and social democratic governments and the so-called 'Troika' (European Commission, European Central Bank and International Monetary Fund) ignited mobilisations in the United States, United Kingdom, Greece, Spain and much of Europe shaking the established political and institutional settlements. Anti-austerity protests were followed by the formation of new political parties and civic organisations conveying the movements' claims and grievances: Syriza in Greece, Podemos and Barcelona En Comù in Spain, the People's Assembly Against Austerity in the United Kingdom, and many others. At the same time, within established parties - the Democrats in the United States and the Labour Party in the United Kingdom - candidates with explicitly socialist and radical ideas and policies in their political programmes, namely Bernie Sanders and Jeremy Corbyn, attained unprecedented popularity, especially among young people. University students, especially in the Anglo-Saxon countries, also mobilised against rising tuition fees and cuts to university funding. Moreover, the inability of economists to foresee the financial collapse gave new momentum to the critique of the paradigms of rationality and utility maximisation underpinning much of neoclassical economics, and a vibrant new student-led movement for economic pluralism emerged demanding more space for heterodox economics in undergraduate and graduate economic degrees.

The growing willingness to critique the status quo was evident not just among groups of activists, students, radical political groups and parties, but also in mainstream newspapers and media outlets, with many articles and op-eds describing capitalism as an unsustainable system and even arguing that the 2008 subprime crisis was a sign of capitalism's imminent, inevitable end (see Jeffries 2008; Mason 2015). The idea that capitalism was on its death-bed also influenced cultural production. For example, in Oakland, Oregon, there was a temporary exhibition titled the "Museum of Capitalism" constituted of a collection of objects, artefacts, installations, archival documents, photos and videos on the "historical phenomenon of capitalism". ${ }^{1}$ Just as we had museums documenting the transition from feudalism to capitalism, the time had now come to treat capitalism as belonging to the past. Thus the need of a museum "for establishing justice for the victims of capitalism and preventing its resurgence". ${ }^{2}$

The mainstreamisation" of critiquing capitalism quickly revived interest in explorations of what post-capitalistic futures would look like. Jeremy Rifkin's book The Zero Marginal Cost Society and Paul Mason's Post-Capitalism: A Guide to Our Future, published respectively in 2014 and 2015, present broadly similar accounts of the society

\footnotetext{
${ }^{1}$ From the website: http://www.museumofcapitalism.org/about/

${ }^{2}$ From the website: http://www.museumofcapitalism.org/about/
} 
of the future: They claim that open-source technological advancements will allow society to produce goods at almost zero marginal cost and in an environmentally sustainable way leaving people with the time, energy, and resources necessary to transform the economy by organising collectively and collaboratively. Albeit problematic in some respects ${ }^{3}$, Paul Mason's argument proves to be a bit more politically audacious than Jeremy Rifkin's one, in its proposal to implement a universal basic income and to progressively socialise monopolies and the financial sector. The notion of "post-capitalism" is now used as a buzzword by academics, journalists, politicians, activists, IT experts, CEOs of multinational companies, and entrepreneurs risking to become an uncritical and harmless ideology. ${ }^{4}$

It is nevertheless evident that we have yet to witness the end of capitalism. If anything, we are spectators of its incredible resilience, of its remarkable capacity to survive its own periodic crises and find new spatial and technological fixes. "Data capitalism" - understood as a form of capitalism where data about individuals' socio-demographic characteristics, tastes, political preferences are harvested through social media and commodified - is only the latest example of capitalism's transformative capacity.

In light of all this, it is clear that, two hundred years after the birth of Karl Marx, his intellectual legacy is more relevant and topical than ever. But engaging with Karl Marx's, Marxian and Marxist theories today has to go beyond a mere critical assessment of contemporary capitalism and its effects. Instead it must be used as a means to push forward theories and practices aimed at producing progressive social change and emancipation. In other words, the engagement with Marx's legacy should be, to put it bluntly, an engagement with his political perspectives. For this purpose, it is useful to go back to the most influential and radical political document ever produced by Karl Marx in his lifetime: The Communist Manifesto. In the Manifesto, Karl Marx and Friedrich Engels state that:

"Our epoch, the epoch of the bourgeoisie possesses [...] this distinctive feature: it has simplified the class antagonism. Society as a whole is more and more splitting up into two great hostile camps, into two great classes directly facing each other: bourgeoisie and proletariat." (Marx and Engels 2016/1848, 5)

If we make an attempt to translate this statement into today's society, we can see that the "two hostile camps" Marx and Engels were describing are nowadays at their most divided: on the one side, we have what activists of the Occupy movement have defined as the 1 per cent - the world's richest elites - and on the other side, the 99 per cent exploited workers in various sectors of the economy, exploited in different ways, through different mechanisms, in different parts of world. How to achieve, in this context, the "society of free and associated producers", the "association of free individuals" that Marx and Engels described in the Communist Manifesto as the society in which "the free development of each is the condition for the free development of all" (Marx and Engels $2016 / 1848,50$ ) is far more challenging. If we agree that the only way to achieve socialism is to transform or supplant capitalism - at least in the form it has assumed in the last two hundred years - we can then consider how this can be achieved. This opens up the age-old and bitter debate within the radical Left on how we should go about changing the system. History is scattered with collective attempts

${ }^{3}$ For a critical review of Paul Mason's excessive optimism towards the emancipatory power of IT, see Fuchs (2016).

${ }^{4}$ On the mainstreamisation of the critique to capitalism in "interesting times", see Žižek (2018) in this issue. 
to achieve socialism, and both their accomplishments and tragic failures have been immortalised. The question, then, is how to transition to a socialist society without replicating the destructive mistakes of the past.

This debate gained renewed vitality after the financial collapse of 2008 , resulting not only in the above-mentioned "mainstreamisation" of critiquing capitalism, but in a renewed interest in Marxist theories. In recent years, critical scholars have come forth with a variety of theories, interpretations and perspectives. The goal of this article is twofold. First, to illustrate how in the last decade a growing number of critical and Marxist thinkers committed to discussing and developing theories of change have started to broaden their focus by including social movements and grassroots initiatives that are "interstitial", i.e. initiatives that are developing within capitalism and are striving to prefigure a post-capitalist society in the here and now without engaging in contentious, violent and revolutionary actions and activities. To achieve this, I mainly focus on the work of four authors: Erik Olin Wright, John Holloway, Ana C. Dinerstein, and Luke Martell. The second goal of this article is to understand why these interstitial movements are getting so much attention from critical scholars and to argue that the time is ripe for establishing a theory of prefigurative social movements. The article closes with some brief reflections on the future of radical thinking that includes an invitation, directed mostly at the young generation of critical and Marxist scholars, to begin a dialogue with theories of change developed within other disciplines, especially political ecology. Succinctly put, I believe that any worthwhile advancement in theories of social change must attribute the same level of centrality to both the social and ecological consequences of expansionary global capitalism.

\section{Utopia as an Emancipatory Strategy}

"Utopia is on the horizon. I move two steps closer; it moves two steps further away. I walk another ten steps and the horizon runs ten steps further away. As much as I may walk, I'll never reach it. So what's the point of utopia? The point is this: to keep walking." (Galeano 1995)

The financial crash of 2008, the worst since the 1930s, has been, similarly but even more powerfully than the previous ones, a crisis of capitalism. A crisis detonated at the heart of the contemporary capitalist system, the United States of America, and has affected, like in an inexorable domino, not only the financial and political institutional institutions of Europe, but also the material lives of millions of its citizens. To many of those affected, this chronology of events was entirely unexpected. But as the Canadian scholar Max Haiven puts it, "the present austerity crises only come to a surprise to the imaginations of those who have, until recently, been the primary beneficiaries of a global system of exploitation" (Haiven 2014, 6). Thus, it was not until the unimaginable happened (at least for the white, middle-class American and European citizen) that a critique of the status-quo and the necessity to rethink the economy and society started to be perceived with a sense of unprecedented urgency. In other parts of the world where the atrocities of capitalist accumulation by dispossession, exploitation and colonial (and neo-colonial) domination have been a reality for centuries, popular mobilisations and community-based, grassroots initiatives have been growing and spreading since the 1990s, forming a "movement of movements" (Mertes et al. 2004) - the multitude (Hardt and Negri 2005). Back in the United States and in Europe, soon after the 2008 financial crash, the concept of "utopia" has started to proliferate in the public debate, in the slogans of activists and social movements, and, increasingly, in the work 
of academics within the social sciences and humanities, including some critical and Marxist scholars. ${ }^{5}$

It is well known that Karl Marx and Friedrich Engels expressed severe criticism of utopian socialism. In the Communist Manifesto, they ironically describe such experiments as "fantastic pictures from the future of society" (Marx and Engels 2016/1848, 69):

"They reject all political, and especially all revolutionary action, they wish to attain their ends by peaceful means, and endeavour, by small experiments, necessarily doomed to failure, and by force of example, to pave the way the new social gospel." (Ibid.)

Only a few pages later, they continue:

"They still dream of experimental realization of their social utopias, of founding isolated 'phalanstères' ${ }^{\text {, }}$ of establishing 'home colonies' [...] and to realize all these castles in the air, they are compelled to appeal to the feelings and purses of the bourgeois." (Ibid., 71)

One point of critique that Marx and Engels develop is that these isolated experimental communities and initiatives, inspired by utopian thinkers like Henri de Saint-Simon, Charles Fourier and Robert Owen, developed in an historical moment (the early 19th century) where the proletariat - the subject of history in Marxian philosophy - was still in its infancy, without any class consciousness or emancipatory ideas that could lead to a revolutionary movement. That said, Marx's perspective on utopian socialism and experimental socialist initiatives presents some exceptions. The most notable is provided by Marx's writings on workers' cooperatives that regarded them as a new form of production emerging within the old capitalistic form ${ }^{7}$ :

"These factories [co-operative factories] show how, at a certain stage of development of the material forces of production, and of the social forms of production corresponding to them, a new mode of production develops and is formed naturally out of the old." (Marx 1894, 456)

After Marx's death, successive generations of Marxist scholars have been looking with scepticism at any intellectual or concrete endeavour inspired by utopian socialism or experimentalism. Marxist scholarship underwent a "statist turn" (Jossa 2005, 12). It was not until the 1960s and the wave of mobilisation started in 1968, that a more positive interpretation of the concept of utopia - seen as the natural tendency of humankind to strive for a better future - regained popularity among critical scholars through

${ }^{5}$ Ruth Levitas' (2016) book Utopia as Method. The Imaginary Reconstitution of Society is an essential read for anyone interested in theories at the crossroads between utopian studies and social theory. It provides also a historical excursus on the use of the concept of utopia in social theory.

6 "A phalanstère (or phalanstery) was a type of building designed for a self-contained utopian community, ideally consisting of 500-2000 people working together for mutual benefit, and developed in the early 19 th century by Charles Fourier. Fourier chose the name by combining the French word phalange (phalanx, the basic military unit in ancient Greece), with the word monastère (monastery)". Retrieved from Wikipedia on April 4 2018. https://fr.wikipedia. org/wiki/Phalanstère.

7 For an exhaustive analysis of Marx's views on workers' cooperatives, see Jossa (2005). 
the writings of Frankfurt School thinkers Ernst Bloch and Herbert Marcuse. In his masterpiece trilogy The Principle of Hope, Bloch (1986/1984) uses the concept of "concrete utopia" to refer to humans' efforts to anticipate the "not-yet" in a continuous, autopoietic process within the present.

One hundred and seventy years after the publication of the Communist Manifesto, utopian thinking, dismissed and mocked by most Marxist intellectuals, is making an impressive come-back into the contemporary debate of the radical Left. Interestingly, as I will illustrate below, all of these intellectuals are using the term escorted by a "legitimising" adjective (real utopia, concrete utopia, interstitial utopia, current utopia) to underline that the utopias they are writing about are profoundly embedded in social reality. The etymology of the word "utopia", coined by Thomas More in 1516, in fact, is composed by the Greek prefix "ou" (non) and the noun "topos" (place) ${ }^{8}$ - a non-place, an impossible place. By consequence, the use made by contemporary social theorists contrasts sharply with the traditional negative conception of the term, historically deployed to refer to unachievable goals, naïve beliefs, and unrealizable projects.

A decade after the financial crash, in the midst of a crisis of imagination (Haiven 2014), the intellectual efforts of a growing number of radical scholars seem to go beyond a mere critique of capitalism. Increasingly, the debate is focusing not only on the individuation of the subjects of emancipation and a strategy aimed at overcoming capitalism, but also on envisaging how society will be constituted in post-capitalist times. As part of this endeavour, scholars have begun trying to identify niches of progressive social change that already exist within capitalist society and to understand their transformative potential, their paradoxes and the causes of their failures.

A prominent Marxist scholar, Erik Olin Wright, uses the term "real utopias" to describe the emancipatory strategies that are built within capitalism but strive to transcend it (see Wright 2018, in this issue). By using the metaphor of an ecological system to describe capitalism, in his acclaimed book Envisioning Real Utopias, Wright (2010) discusses three, non-mutually exclusive, emancipatory transformations to overcome capitalism: the ruptural, the symbiotic, and the interstitial. Whereas the first two strategies refer to disruptive revolutions (the former) and positive systematic cooperation between social forces (the latter), the third emancipatory strategy - the interstitial one - is described as a "process of metamorphosis in which relatively small transformations cumulatively generate a qualitative shift in the dynamics and logics of a social system" (Wright 2010, 321). Interstitial activities and processes develop as niches within the old system, despite the old system, prefiguring a post-capitalist system. While on the one hand, Wright recognises that a number of interstitial activities - worker-owned coops, ecological communities, fair trade networks - can play a role in fostering social change, he is, on the other hand, much more sceptical when it comes to assessing their potential for overcoming the capitalist system. In the piece written for the present special issue, Wright (2018) argues that if they ever "grew to a point of threatening the dominance of capitalism, they would simply be crushed".

Interstitial activities assume a pivotal role also in John Holloway's theory of emancipation. Distancing himself from orthodox Marxism, Holloway's perspective is centred on the struggle for recognition and social validation of the "human doing" outside the logic of capital (Holloway 2002a, 29). These concrete human actions, kept free from being transformed into "abstract labour" in the constant process of subsumption of

${ }^{8}$ The etymology of the word 'utopia' is a contested terrain. In fact, another possible interpretation sees the word as composed by the prefix 'eu' (Greek for 'good') and 'topos' (Greek for 'place') thus forming the word 'eutopia'. The meaning then would be 'the good place'. 
capitalism, constitute "cracks" within the dominant capitalist system. These cracks are spaces where "we stop making capitalism" (Holloway, quoted in Dinerstein 2012, 529), spaces where the interstitial revolution takes place. While Erik Olin Wright declares that the state could facilitate emancipatory non-capitalist relations within the existing capitalist regime $(2018,10)$, Holloway's position is that interstitial initiatives are exactly linked to the necessity of rejecting the role of the state. "Change the World Without Taking Power", claims the title of his provocative book published in 2002 (Holloway 2002a). One could not be faulted for thinking that the perspectives of Wright and Holloway are irreconcilable. It is nonetheless possible to find common ground. Both recognise how problematic it is to deploy the Marxian concept of the "proletariat" in contemporary theories of emancipation. In other words, they both point out how difficult it is to identify the revolutionary subject as such. On the one side, for Wright this requires "bringing together people from a much more heterogeneous set of structural locations in the economy and society" (Wright 2018). Instead, for Holloway the working class "is permanently being constituted in a process that is based in the constant and violent process of separation of object from the subject" (Dinerstein 2012, 528).

What is particular to Holloway's theory of interstitial revolution is the emphasis placed on the urgency of 'doing here and now'. Instead of postponing the time horizon for a revolution capable of overthrowing capitalism, Holloway underlines the need to collectively imagine alternative futures and to enact them and replicate them in the present. This idea has had a great influence on many social movements in the last two decades, the most notable examples being the Zapatista movement ${ }^{9}$ and the Occupy Wall Street movement. Holloway's provocative writings have generated a vibrant debate among radical thinkers and inspired a new generation of scholars to further develop and elaborate his intellectual legacy.

Among them, the work of Ana Cecilia Dinerstein and her colleagues in the book Social Sciences for an Other Politics: Women Theorizing without Parachutes (Dinerstein 2016) is particularly pertinent, since it fruitfully attempts to combine Bloch's perspective on the "not-yet" and concrete utopia with Holloway's theory of interstitial revolution. Defining herself as an Open Marxist, Dinerstein focuses her attention on the social movements of Latin America such as the Zapatistas, the piqueteros in Argentina, and the indigenous struggles for self-determination. In her view, concrete utopias "denaturalize" economic categories of employment, production, and consumption through experiential and experimental practices - what Holloway terms the "human doing". Concrete utopia "emerges and evolves within, against and beyond the social relation of capital and its institutions. Concrete utopia is not outside capital" (Ibid., 52). To incorporate concrete utopias into a critical Marxist appraisal of political economy, Dinerstein boldly calls for a "decolonization of Marxism", that is a call to read Marxian economic writings in the key of Bloch's theory of hope (Ibid., 59).

The final example of the return of utopian thinking among Marxist scholars worth highlighting is Luke Martell's (2018) recently published article "Utopianism and Social Change'”. Martell shows, through an exhaustive excursus on modern and contemporary utopian scholarly production, that "current utopias ground the future in current experiment and demonstration" (Martell 2018, 7). His argument goes against what he defines as the "false dichotomies" posed by the critics of utopian thought: utopia has been criticised for not being a materialist solution and for constituting a potential threat to pluralism and liberalism. Warning against the perils of totalitarian utopias resulting in the regimes of the 20th century, Martell concludes by addressing the question of

\footnotetext{
${ }^{9}$ For a comment on the relevance of the Zapatista movement, see Holloway (2002b).
} 
whether utopias can foster or undermine positive social change. His answer is that the "current utopias" (as opposed to what he calls "future utopias"), such as intentional communities, free universities, or co-ops "can represent the material and conflictual basis for change within current society, rather than a retreat from this" (Ibid., 10). Similar to Dinerstein, he claims that they "pursue change based on material experience [...] rather than on theory or ideology about the future" (Ibid., 7).

At this point the reader is probably wondering whether there is a substantial difference between Martell's current utopia, Dinerstein's concrete utopia, and Wright's real utopia, in other words, whether they are referring to the same social phenomena. Wright's utopia is defined as "real" since it is conditional on its feasibility and achievability (Dinerstein 2017), whereas Bloch's concrete utopia deployed by Dinerstein points at transforming "hope from an emotion to a political problem for the capital" (Ibid.). ${ }^{10}$ Finally, Martell's point of view can be placed somewhere in between Wright's and Dinerstein's positions: concerned about underlining its materialist nature and its potential emancipatory role, he stresses that it is precisely its experimental and experiential nature that is crucial for wider social change in the future.

To proceed with my argument, though, I find it more useful to highlight what all the above-mentioned scholars have in common. It is undeniable that they are all talking about activities, experiments and initiatives that, despite their small scale and the difficulties they encounter in surviving within capitalism (and not being co-opted by it), assume an important role in the critical study of capitalism because they are striving to concretise alternative forms of social reproduction through transformative everyday practices.

What is it, then, that we are talking about?

\section{Beyond Resistance: A Sociology Of and For Prefigurative Social Movements}

"We live in capitalism, its power seems inescapable. So did the divine right of kings. Any human power can be resisted and changed by human beings." (Le Guin 2014)

In the last two decades, several initiatives have been mushrooming around the world: community and urban gardens, worker-owned coops, producer-consumer coops, ecological and intentional communities, co-housing coops, food sovereignty initiatives, occupied and worker-managed factories, participatory budgeting, and direct democracy at local level. At the same time, revolutionary and contentious social movements, the most notable examples being the Zapatistas in Mexico and the People's Protection Units (YPG) and the Women's Protection Units (YPJ) in Rojava (Federation of Northern Syria), have placed at the core of their strategies principles of direct democracy, cooperative economy, ecology and women's leadership, influenced (especially the latter) by the eco-feminist and political-ecological thought of scholars like Silvia Federici and Murray Bookchin. Similarly, hard hit by the consequences of the austerity measures imposed by the Troika, Greek civil society started to organise from below, forming a constellation of grassroots initiatives centred on the values of solidarity and

${ }^{10}$ Dinerstein (2017) thoroughly examines the difference between Wright's "real utopias" and Bloch's (and her) formulation of "concrete utopia" in a blog post titled "Concrete Utopia. $(\mathrm{Re})$ producing Life in, against and Beyond the Open Veins of Capital", published in December 2017 on Public Seminar, a blog project by The School for Social Research in New York. 
mutualism followed by other groups in countries like Italy, Spain, and Portugal. In the field of social sciences and humanities, the debate on these grassroots initiatives has gained prominence but a comprehensive theoretical and analytical framework is still lacking.

My argument is that all these experiences, putting aside their interstitial nature and the different socio-economic and political contexts from which they have emerged, share an important trait: they are prefigurative, meaning that they embody their ultimate goals and their vision of a future society through their ongoing social practices, social relations, decision-making philosophy and culture. These interrelated processes, unfolding over time, involve collective experimentation with the production and circulation of new meanings and future-oriented social norms (Yates 2015). In this sense, we can hypothesise that we are witnessing the emergence of a new wave of social movements differing in its features, claims and strategies from the historical class-based movements of the 19th century, from the new social movements of the Sixties and Seventies, and even from the alter-globalisation movement of the late Nineties and early 2000 s. If these prefigurative social movements constitute the real/concrete/current utopias that new generations of critical scholars and Marxists are starting to look at as potential subjects of emancipation, it becomes a crucial task, then, to disentangle their ontological, epistemological and phenomenological characteristics. In other words, the task is to build a sociology of and, most importantly, for prefigurative social movements.

The term "prefigurative" appears for the first time in the writings of the American anthropologist Margaret Mead in 1973. She uses the term to indicate the advent of a "prefigurative culture" where "it will be the child - and not the parent and grandparent - that represents what is to come" (Mead 1973, 204). In this sense, prefigurative culture is future-oriented and differs from "postfigurative" and "configurative" cultures: In the former, cultural transmission is strongly affected by the worshipping of ancestors and traditions from the past, whereas the latter - arising after the collapse of a postfigurative culture - has a transitional nature and is present-oriented. It is not until 1977, however, that the word appears in critical scholarship, in Carl Boggs' (1977) essay "Marxism, Prefigurative Communism, and the Problem of Workers' Control' published in the magazine Radical America. In his essay, pointing at the "failure of Marxism to spell-out the process of transition", Boggs uses some historical examples, like the Biennio Rosso in Italy and the uprisings of students and workers in the 1968 French May to outline the defining features of prefigurative communism:

"Prefigurative strategy, on the other hand, views statism and authoritarianism as special obstacles to be overturned; its goal is to replace the bureaucratic state with distinctly popular institutions. Ideally, this tradition expresses three basic concerns: fear of reproducing hierarchical authority relations under a new ideological rationale, criticism of political parties and trade unions because their centralized forms reproduce the old power relations in a way that undermines revolutionary struggles, and commitment to democratization through local, collective structures that anticipate the future liberated society" (Boggs 1977). ${ }^{11}$

The concept of prefiguration gained popularity with the wave of alter-globalisation movements in the late Nineties (Maeckelbergh 2011) and then became one of the main tenets of the Occupy Wall Street movement (Graeber 2013). Ten years after the financial crash, prefiguration - conceived as the need to live and strive to reproduce in the ${ }^{11}$ Accessed online at this link: https://libcom.org/library/marxism-prefigurative-communism-
problem-workers-control-carl-boggs. 
present the kind of society we envision for the future - is central to all the social movements and grassroots initiatives mentioned above. For them prefiguration plays an even more central role than it did in the alter-globalisation and the Occupy movements, where it was reflected mostly in the practices of horizontalism and direct democracy deployed in their decisional processes. "This is what democracy looks like" is the chant that demonstrators shouted while marching on the streets of Seattle during the protests against the WTO in 1999. Today, looking at the ecological communalism of the Protection Units in Rojava or the focus on radical everyday lifestyles of certain intentional communities, it is clear that prefiguration is conceived by these movements as the need to rethink holistically our relationship towards nature, the economy and society, or - as Dinerstein $(2017,53)$ puts it - to "denaturalize" capitalist logic.

Nowadays prefiguration can be seen as part of the repertoire of action of several movements and grassroots initiatives. Some of them are defending spaces from capitalist accumulation. Close to the North-Western French coast, in an area called Notre Dame de Landes, a movement of people have spent the last ten years occupying and living on an agricultural plot of land to prevent an airport being built on it. In the ZAD Zone à Defendre, a French acronym for "area to defend" - contentious action against police attempts to evict the activists (the latest eviction attempt is currently being resisted at the moment of writing in April 2018) is blended together with prefigurative practices such as permaculture, organic farming, and the production of goods like dairies and bread. Other groups deploy prefigurative practices to restore spaces of former capitalist production. RiMaflow and Vio.Me are two examples. Two former factories, the first in the North of Italy and the second close to the Greek city of Thessaloniki, have both been recovered by dismissed employees after they were closed-down in the early 2010s. The conversion of these two factories did not only involve the restarting of new productive activities through workers' self-management, it also led to a flourishing of solidarity activities (e.g. free medical ambulatories) and international networks with other worker-owned cooperatives in Europe and Latin America. Finally, for a third group of movements, prefiguration is concretised through the creation of new spaces through experimentation with alternative modes of producing, consuming and living. The most notable examples are producer-consumer co-ops, intentional communities, and eco-villages. The latter can be described using the prism of Paolo Virno's "theory of exodus", according to which "the most powerful way of opposing capitalism and the liberal state is not through direct confrontation but by means of engaged withdrawal" (Graeber 2004, 60). ${ }^{12}$

The diffusion of movements deploying - explicitly or implicitly - prefigurative practices and discourses has given rise to a range of critical appraisals that question the effectiveness of prefiguration in opposing or supplanting capitalism. At the heart of these critiques, we find Chantal Mouffe's argument that the Occupy movement failed in constructing an anti-hegemonic narrative and in identifying precise, targetable "nodal points of power" against which to direct the movement's agonistic efforts (Mouffe 2013,

12 In the same book, David Graeber continues: "A revolution on a world scale will take a very long time. But it is also possible to recognize that it is already starting to happen. The easiest way to get our minds around it is to stop thinking about revolution as a thing - 'the' revolution, the great cataclysmic break - and instead ask 'what is revolutionary action?'. We could then suggest: revolutionary action is any collective action which rejects, and therefore confronts, some form of power or domination and in doing so, reconstitutes social relations, even within the collectivity - in that light. Revolutionary action does not necessarily have to aim to topple governments. Attempts to create autonomous communities in the face of power [...], would, for instance, be almost by definition revolutionary act" (Graeber 2004, 45). 
75). According to Mouffe, the Occupy movement lacked a political strategy capable of establishing precisely who the 1 per cent - the enemy - was, and was weakened by its unwillingness to translate and organise claims in the sphere of institutional and representative politics (see Decreus et al. 2014). If we expand the focus to include what I argue to be the diverse constellation of prefigurative movements that have flourished since Occupy, it is easy to see how Mouffe's critique can be directed at them as well. It is in fact a difficult and arduous task to recognise who or what constitute the nodal points of power for a worker's co-operative, urban garden, or ecovillage, although it is easier for those initiatives that include contentious actions in their repertoire like the above mentioned ZAD or the protection units in Rojava. The red thread connecting all of these movements is precisely that they seek to push towards the realisation of a post-capitalist society by embodying it in the present. By and large, then, the analytical dichotomy between "strategic" and "prefigurative" movements put forward by Mouffe and others does not help us to understand their emancipatory potential (Maeckelbergh 2017).

In an attempt to constructively re-interpret the Occupy movement and the Indignados movement in light of Mouffe's critique, Decreus et al. $(2014,145)$ affirm that "if the terrain of struggle cannot be clearly located or determined, social movements will have to create it by themselves. It is in relation to this observation, that one should understand the symbolic and artistic character of radical protest movements today". This point reduces prefigurative practices to symbolic, artistic and theatrical acts and, while it might be enough to capture the role of prefiguration within the Occupy and Indignados movements, it certainly does not do so for the myriad of movements that we are addressing in this article. We are left then with some vexing questions: Who constitutes the collective identity of these movements, the "we"? Can we locate "the political" in these movements or are they - as some would argue - mere post-ideological, postpolitical and ephemeral laboratories?

Revisiting Alberto Melucci's volume Challenging Codes published in 1996 provides timely hints for reflection. Many of the features described by Melucci in his book have eventually been deployed by subsequent generations of social movement scholars to refer to the alter-globalisation movement and still prove valuable to understand prefigurative movements. Movements "announce what is taking shape even before its direction and content has become clear" (Melucci 1996, 1), states the author in the introduction. These movements claim "a desire for immediate control over the conditions of existence and to claim independence from the system" (Ibid., 102). At the same time, these prefigurative movements aim at a participation that is not mediated by institutional and representative politics, which is why they display disinterest in seizing state power, and do not recognise a separation between the public and the private sphere. By consequence, instead of being post-political, prefigurative movements end-up (re)politicizing what is usually non-politicized: everyday life, the spaces of private, economic and social (re)production through "conscious processes of organization" and not-necessarily through confrontational actions (Melucci 1996, 77).

It takes little to realise that a serious engagement with these movements calls for a re-conceptualisation of social movements and a recognition that traditional frameworks utilised to assess the effectiveness of movements are inadequate. In the case of prefigurative movements, social change is achieved through a "plural configuration of practices" and iterative processes of experimentation, re-organisation, and re-imagination (Yates 2015). In the last ten years, we have witnessed an upsurge of these movements that, rather than constituting "isolated" units - or islands like in Thomas More's utopia - are locally rooted, but closely interconnected through national and 
transnational networks. Examples are the RIPESS network of social and solidarity economy initiatives, the Co-operative Housing International, the Global Ecovillage Network, La Via Campesina, the Transition Town network, or Genuino Clandestino in Italy. The list could go on to form a heterogeneous and global tapestry: some networks have been established more recently than others, some are informal rather than formal, some collaborate with institutions and international organisations while others are keen to protect their autonomy from national and supranational institutions.

The question is if and to what extent they are managing to "transcend capitalism" as Erik Olin Wright (2018) puts it. Although a discussion on the criteria and temporalities required to determine the successes or failures of prefigurative movements is beyond the scope of this article ${ }^{13}$, a brief reflection on the ways in which prefigurative movements bring about social change leads us to a crucial realisation: Every effort to prefigure a post-capitalist society in the "here and now" is quickly destined to be confronted by the dominant mechanisms of primitive accumulation, expropriation, privatisation of the commons and commodity fetishism (see the contributions by Harvey and Hardt/Negri in this special issue). In fact, prefigurative movements are struggling to survive in the context of capitalism in which they are immersed.

At this point it is useful to share an illustrative example. I recently visited one of the biggest and oldest intentional communities in the world, where a lush green forest is growing in a previously desert plain thanks to a massive reforestation project by its inhabitants. Permaculture and organic farms are producing fruits and vegetables for a large part of the community. The rest of the products needed are bought from surrounding local producers and distributed through a co-operative supermarket where inhabitants can go and take as much as they need as part of their monthly allowance. All of the electricity consumed in the community is produced off-grid thanks to solar and wind energy. Cutting-edge technologies are deployed to calculate the most efficient way to irrigate cultivated lands without wasting the precious and scarce resource that is water. Waste is kept to a minimum through conscious consumption, recycling and re-utilisisation. The inflow of cash coming from hundreds of thousands of tourists visiting every year to attend activities, workshops, and courses are re-distributed by a central committee to each inhabitant through a monthly basic income. All that said, the city plan that this community is following to reach its target of 50,000 inhabitants is being challenged by encroaching private property speculation. The rising influx of tourists and visitors in the last years has resulted in a boom of guest-houses and hotels being built in nearby villages thus driving up the prices of land and gentrifying the surrounding areas. This is making it very difficult for the intentional community to preserve what they call the 'green belt' (the forest grown thanks to their reforestation efforts in the last 50 years) on which they plan to expand. At the same time, many inhabitants are struggling to survive on the monthly allowance and are therefore working 'outside' of the intentional community. This creates economic inequalities between those who rely solely on the internal basic allowance and those who earn a salary by working in the capitalist economy. The relationship with the state is also problematic. If on the one side, the state has been sponsoring and financing some of their activities and projects, on the other side tensions are emerging between those within the community who want to maintain autonomy and prevent co-optation and those who see an opportunity to scale-up and disseminate initiatives and practices.

Borrowing Chatterton's and Pickerill's definition, prefigurative movements such as this one can be characterised as being "anti, despite, and post-capitalism" movements

\footnotetext{
${ }^{13}$ On this point, see Maeckelbergh (2017).
} 
$(2010,14)$. Labels aside, having to interact with the capitalist context (the state and the market) is inevitable for prefigurative movements. Here is the most controversial point: Isn't it exactly through the interaction with the capitalist context that prefigurative movements are going to erode it? Isn't it exactly when a municipality, a state, a supranational institution or even a multinational corporation starts to recognise, for instance, that the social and solidarity economy is a 'best practice' and thus starts to encourage its growth through funds and favourable policies, that prefigurative movements can consider themselves as having succeeded in their goals? Or is this co-optation nullifying their efforts? ${ }^{14}$ The answer to these questions are far from straightforward. In his essay for the present special issue, Wright (2018) states that "the problem [...] is whether or not it is possible to erode the dominance of capitalism within this complex economic system by expanding the weight of alternative, non- capitalist economic activities organized through democratic-egalitarian-solidaristic relations". In Wright's view, in sum, transcending capitalism is inevitably linked to the incremental expansion of alternative economic practices over traditional capitalistic ones. This requires rethinking the conventional modes through which work, production and consumption are organised in contemporary society.

In an attempt to provide a framework to interpret collectives engaging in political consumerism as a form of political participation, Forno and Graziano coined the definition of "sustainable community movement organizations" to define "a social movement organization that has the peculiarity of mobilizing citizens primarily via their purchasing power and for which the main battlefield is represented by the market where its members are politically concerned consumers" $(2014,142)$. Whether or not "battling" in the marketplace is enough to transcend capitalism can be discussed, as well as the fact that purchasing power is directly dependent upon the availability of economic resources which, we know, are unequally distributed across the population. While Forno and Graziano are primarily concerned with the shift in consumers' "consciousness", the encompassing link between work, production and consumption to realise a post-capitalist society is at the heart of theories about the "commons" created by a group of radical scholars including J.K. Gibson-Graham, Silvia Federici, George Caffentzis, Peter Linebaugh, and Massimo de Angelis. From the perspective of this group of scholars, a post-capitalist society should be achieved through the process of commoning, that is "a specific multifaceted social labour through which commonwealth and the community of commoners are (re)produced together with the reproduction of stuff, social relations, affects, decisions, cultures" (De Angelis 2017, 123). This process, which reminds us about Bloch's autopoietic process towards the "not-yet" possible futures, comprises two essential moments: decision making and "doing together". Interestingly, De Angelis points out that there is a difference between social movements and the "commons": The former are focused on claiming for alternatives, the latter embody the alternatives through practices. A synthesis can be found in what he calls "commons movements", i.e. movements that engage in both protest and practice.

In her contribution to the present special issue, Silvia Federici concludes by invoking the need to "refocus our politics on the production of our material life, and the life of the ecosystems in which we live" (Federici 2018). Prefigurative movements are moving in this direction. They are not merely movements of resistance against the status quo, but they are trying, through their concrete practices, to oppose capitalism as a

\footnotetext{
${ }^{14}$ On the risks of co-optation in the case of co-operatives, see Sandoval (2016).
} 
moral system, a system dictating what is 'valuable' and what is not. ${ }^{15}$ In other words, prefigurative movements have the goal of going beyond capitalist morality and normativity and coming forth with alternative forms of moral, economic and social (re)production. ${ }^{16}$ Prefiguration, to sum up, is now an integral part of contemporary social movements, and - as the various examples above show - various interpretive frameworks are starting to emerge. Hence my call to join forces and establish a sociology of and for prefigurative social movements. The "for" is as important as the "of": through their work scholars can help these movements to be self-reflexive, to think about themselves as pioneers of change in a process of trial and error that characterises all experimentations.

\section{Conclusion}

"Are there still other possibilities? Of course there are [...] Whichever option is chosen, it will not be the end of history, but in a real sense its beginning. The human social world is still very young in cosmological time. In 2050 or 2100, when we look back at capitalist civilization, what will we see?" (Immanuel Wallerstein 2014, 163)

This article set out to describe how, ten years after the financial collapse of 2008, there is a growing awareness of the unsustainability of capitalism. Despite the criticism expressed by Marx towards socialist utopianism and experimentalism, two hundred years after his birth, there is also a resurgent interest among new generations of Marxist scholars in the idea of utopia, conceived as a continuous process of striving in the present towards an alternative society. Terms such as "real utopia", "concrete utopia" and "current utopia" are now being deployed by scholars to describe the emergence of "new social movements" that are not only opposing capitalism but also prefiguring post-capitalist societies. These movements are re-thinking and re-politicising conventional modes of production, consumption and living by defending, restoring and creating spaces of resistance and experimentation.

Within the social science more broadly we have seen a flourishing of parallel literatures interested in these movements, all published within the same temporal span (2008-2018) by scholars coming from different, albeit adjacent, disciplines: social theory, political economy, political ecology, social movement studies, sustainability transitions studies, consumer studies and environmental studies. Due to the simultaneous way in which these literatures have emerged it is difficult to find substantial cross-references between them, although they are clearly analysing the same social phenomena. Cross-pollination that transcends disciplinary boundaries would therefore be enormously fruitful for the development of new theoretical and analytical frameworks.

More than providing a rebuttal to those scholars who critique prefigurative movements for being inefficient, post-political and post-ideological, this article constitutes an invitation firstly to create an interdisciplinary sociology of prefigurative social movements, and secondly for them by engaging in a constructive dialogue that can enhance

${ }^{15}$ On capitalism as a moral system, see Max Haiven's and Alex Khasnabish's book The Radical Imagination (published by Verso in 2014) and the website of their project (ceased in 2017): http://radicalimagination.org/.

${ }^{16}$ In the book Sociology, Capitalism and Critique, Hartmut Rosa comes forth with the concept of resonance as a new mode of existence opposed to alienation (in its two forms: repulsion and indifference) and evokes the prerequisite of de-synchronizing from capitalist acceleration at macro, inter-social and micro levels (Dörre, Lessenich and Rosa 2015, 280-303). 
their emancipatory and transformative potential and help them to think through strategies and manage challenges, rather than simplistically dismissing them. "Fellow-travelling" (Keucheyan 2014) with prefigurative social movements could create a dialogical process in which practice is nourished by research as much as research is nourished by practice. To conduct transdisciplinary research effectively, though, we need be open to experimenting with participatory, visual and creative methods that can help overcome the "observer-researcher" modality in which the former is simply the passive object of study. This may in turn require further reflections about alternative ways of producing and disseminating knowledge outside of traditional academic institutions that often act as constraints on innovation.

Finally, it is time to lay the age-old debate about whether change can be achieved best through strategies aimed at seizing political and institutional power or through grassroots, prefigurative initiatives to rest. Both are striving to resist and supplant capitalism and establish more just and egalitarian economic systems. The key question moving forward is how strategies at the macro and micro level can be connected and fine-tuned to attain the common goal which has so far proved elusive. This arguably represents one of the greatest challenges for the future of radical theory.

\section{References}

Bloch, Ernst. 1986/1984. The Principle of Hope. Cambridge, MA: The MIT Press.

Boggs, Carl. 1977. Marxism, Prefigurative Communism, and the Problem of Workers' Control. Radical America 11 (6): 99-122. Accessed 20 April, 2018: https://libcom.org/library/marxism-prefigurative-communism-problem-workers-control-carl-boggs

Chatterton, Paul and Jenny Pickerill. 2010. Everyday Activism and Transitions Towards PostCapitalist Worlds. Transactions of the Institute of British Geographers 35 (4): 475-490.

De Angelis, Massimo. 2017. Omnia Sunt Communia: On the Commons and the Transformation to Postcapitalism. London: Zed Books.

Decreus, Thomas, Matthias Lievens and Antoon Braeckman. 2014. Building Collective Identities: How New Social Movements Try to Overcome Post-Politics. Parallax 20 (2): 138148.

Dinerstein, Ana C. 2017. Concrete Utopia: (Re)producing Life in, against and beyond the Open Veins of Capital. Accessed April 10, 2018: http://www.publicseminar.org/2017/12/concrete-utopia/

Dinerstein, Ana C. 2016. Social Sciences for Another Politics. Women Theorizing Without Parachutes. Cham: Palgrave MacMillan.

Dinerstein, Ana C. 2012. Interstitial Revolution: On the Explosive Fusion of Negativity and Hope. Capital \& Class 36 (3): 521-540.

Dörre, Klaus, Stephan Lessenich and Hartmut Rosa. 2015. Sociology, Capitalism, Critique. London: Verso.

Federici, Silvia. 2018. Marx and Feminism. tripleC: Communication, Capitalism \& Critique 16 (2): 468-475.

Forno, Francesca and Paolo R. Graziano. 2014. Sustainable Community Movement Organisations. Journal of Consumer Culture 14 (2): 139-157.

Fuchs, Christian. 2016. Henryk Grossmann 2.0: A Critique of Paul Mason's Book "PostCapitalism: A Guide to Our Future". tripleC: Communication, Capitalism \& Critique 14 (1): 232243.

Galeano, Eduardo. 1995. Walking Words. New York: W.W Norton \& Sons.

Graeber, David. 2004. Fragments of an Anarchist Anthropology. Chicago, IL: Prickly Paradigm Press.

Graeber, David. 2013. The Democracy Project: A History, A Crisis, A Movement. New York: Spiegel and Grau. 
Haiven, Max and Alex Khasnabish. 2014. The Radical Imagination: Social Movement Research in The Age of Austerity. London: Zed Books.

Haiven, Max. 2014. Crises of Imagination, Crises of Power. Capitalism, Creativity and The Commons. London: Zed Books.

Hardt, Micheal and Antonio Negri. 2005. Multitude: War and Democracy in the Age of Empire. London: Penguin Press.

Holloway, John. 2002a. Change the World Without Taking Power. London: Pluto Press.

Holloway, John. 2002b. Zapatismo and the Social Sciences. Capital \& Class 26 (3): 153-160.

Jeffries, Stuart. 2008. Karl Marx's Guide to the End of Capitalism: A Primer. The Guardian Online, October 21, 2008. Accessed 28 April, 2018. https://www.theguardian.com/politics/2008/oct/21/creditcrunch-globaleconomy

Jossa, Bruno. 2005. Marx, Marxism and the Cooperative Movement. Cambridge Journal of Economics 29 (3): 3-18.

Keucheyan, Razmig. 2014. The Left Hemisphere: Mapping Critical Theory Today. London: Verso.

Le Guin, Ursula K. 2014. National Book Awards, 19 November [acceptance speech].

Levitas, Ruth. 2016. Utopia as Method: The Imaginary Reconstitution of Society. Basingstoke: Palgrave MacMillan.

Maeckelberg, Marianne. 2017. The Prefigurative Turn: The Time and Place of Social Movement Practice. In Social Sciences for an Other Politics: Women Theorizing Without Parachutes, edited by Ana C. Dinerstein, 121-134. Basingstoke: Palgrave MacMillan.

Maeckelbergh, Marianne. 2011. Doing is Believing: Prefiguration as Strategic Practice in the Alterglobalization Movement. Social Movement Studies 10 (1): 1-20. Accessed April 10, 2018: http://dx.doi.org/10.1080/14742837.2011.545223

Martell, Luke. 2018. Utopianism and Social Change. Capital \& Class. Accessed April 10, 2018: https://doi.org/10.1177/0309816818759230

Marx, Karl and Friedrich Engels. 2016/1848. The Communist Manifesto. London: Verso.

Marx, Karl. 1894. Capital. Volume III. London: Penguin.

Mason, Paul. 2015. The End of Capitalism Has Begun. The Guardian Online, July 17, 2015. https://www.theguardian.com/books/2015/jul/17/postcapitalism-end-of-capitalism-begun

Mason, Paul. 2016. Post-Capitalism: A Guide to Our Future. New York: Farrar, Straus and Girioux.

Mead, Margaret. 1973. Prefigurative Cultures and Unknown Children. In Youth: Divergent Perspectives, edited by Peter K. Manning, 193-206. New York: John Wiley and Sons.

Melucci, Alberto. 1996. Challenging Codes. Collective Action in the Information Age. Cambridge: Cambridge University Press.

Mertes, Tom, ed. 2004. A Movement of Movements: Is Another World Really Possible? London: Verso.

Mouffe, Chantal. 2013. Agonistics: Thinking the World Politically. London: Verso.

Rifkin, Jeremy. 2014. The Zero Marginal Cost Society. New York: Palgrave MacMillan.

Sandoval, Marisol. 2016. What would Rosa do? Co-operatives and radical politics. Soundings, 2016, 63 (14): 98-111.

Wallerstein, Immanuel. 2014. Historical Capitalism. London: Verso.

Wright, Erik Olin. 2018. The Continuing Relevance of the Marxist Tradition for Transcending Capitalism. tripleC: Communication, Capitalism \& Critique 16 (2).

Wright, Erik Olin. 2010. Envisioning Real Utopias. London: Verso.

Yates, Luke. 2015. Rethinking Prefiguration: Alternatives, Micropolitics and Goals in Social Movements. Social Movement Studies 14 (1): 1-21. Accessed 10 April, 2018. https://doi.org/10.1080/14742837.2013.870883

Žižek, Slavoj. 2018. The Prospects of Radical Change Today. tripleC: Communication, Capitalism \& Critique 16 (2): 476-489. 


\section{About the Author}

Lara Monticelli

Lara Monticelli is an independent researcher and prospective Assistant Professor and Marie Skłodowska-Curie fellow at the Department of Management, Politics and Philosophy at Copenhagen Business School (from September 2018 onwards) where she will continue her investigation on radical lifestyles, prefigurative social movements, and alternatives social-economic practices. Lara is especially interested in how prefigurative movements re-politicize and re-configure everyday life, thus representing radical attempts to embody the critique to contemporary capitalism and envision alternative futures. She is the co-founder of the newly established research network 'Alternatives to Capitalism' within the Society for the Advancement of Socio-Economics (SASE). From 2015 to 2017, she worked as a post-doctoral research fellow at the Institute for Humanities and Social Sciences at Scuola Normale Superiore di Pisa (Italy). 